\title{
THE LOCATION DECISIONS OF MULTINATIONALS AND THE CULTURAL LINK: EVIDENCE FROM SPANISH DIRECT INVESTMENT ABROAD
}

\author{
Salvador Barrios \\ Juan Miguel Benito-Ostolaza \\ D.T.2008/04
}




\title{
THE LOCATION DECISIONS OF MULTINATIONALS AND THE CULTURAL LINK: EVIDENCE FROM SPANISH DIRECT INVESTMENT ABROAD*
}

\author{
Salvador Barrios ${ }^{* *}$ and Juan Miguel Benito-Ostolaza ${ }^{*}$
}

\begin{abstract}
We examine the way in which differences in language and culture may affect direct investment decisions. We use a discrete choice approach to model the location decisions of multinationals in which cultural links, language differences, distance and market access are accounted for. This model is used to study the determinants of the location decisions of Spanish multinationals over the period 19881997. Cultural ties, including language, are found significantly to affect the location decisions of Spanish firms abroad. These ties, also explain the leading position of Spanish multinationals in Latin American countries compared to more advanced home countries such as the US, Germany and the UK. The specific advantage of Spanish multinationals together with the rapid economic development of the Spanish economy, which has traditionally been a large FDI-recipient, tend to corroborate the view that intangible assets such as culture and language proximity do matter in understanding net outward investment patterns.
\end{abstract}

Keywords: Foreign Direct Investment, multinational companies, Spain, Culture, language.

JEL Classifications: A13, D21, F23, M21

\footnotetext{
* The opinions expressed in this paper are not necessarily those of the European Commission. Any errors are ours alone. This paper was written before the first author joined the European Commission. The second author is grateful for partial financial support from the Spanish Ministry of Science and Technology under projects SEJ2006-11510 and HUM2006-01277.

** Directorate-General for Economic and Financial Affairs, European Commission. BU-1 0-117, Avenue de Beaulieu, 11160 Brussels, Belgium. Tel: +32 (0)2 2967987. Fax: +32 (0)2 2993505. Email: salvadorbarrios@gmail.com.

* Departamento de Economía. Universidad Pública de Navarra.Campus Arrosadía s/n, 31006 Pamplona. Spain. Tel: +34 948168970. Fax: +34 948169721. E-mail: jon.benito@unavarra.es.
} 


\section{Introduction}

Since the mid-1980s and the entry of Spain into the European Community, Foreign Direct Investment (FDI) has traditionally played an important role in the internationalisation and economic development of the country, see Guillén (2005). Interestingly, during the past decade Spanish firms have started to invest massively abroad, mainly in other EU countries but also elsewhere, particularly in Latin American countries. In the latter case in particular, Spanish multinationals have been very active and have attained leading positions in the banking, energy and manufacturing industries. For instance, between 1999 and 2004 Spain became by far the leading investor in Latin American countries with direct investment amounting to 75 billion Euros while the US, the second-biggest investor and traditionally the leading investor in this region of the World, invested 58 billion Euros. ${ }^{1}$ While some of these developments may be due to the fact that Spain experienced sustained economic growth during that same period, and a growing internationalisation of its economy, these elements are unlikely to explain the prominence of Spanish FDI in Latin America. For instance, in comparisons of Spanish economic influence using GDP, exports or even total FDI figures Spain stands far behind countries such as the US and Japan but also behind other EU countries such as Germany, France and the UK. It has sometimes been argued that the spectacular outflows of FDI from Spain to Latin America are due to the strong advantage held by Spanish companies in the shape of their specific cultural ties with most Latin American countries, see Toral Cuetos (2004). In addition, there is considerable evidence showing that a sizeable amount of FDI came from non-Spanish companies established in Spain who used the country as a base for developing investment and trade activities with Latin America. See, for instance, Camino Blasco and Pradas Poveda (2001).

Previous evidence suggests that the surge and magnitude of Spanish FDI going to Latin America is explained by other than purely economic reasons, see, for instance, Galan et al. (2007). The

\footnotetext{
${ }^{1}$ Source: Eurostat, European Commission and authors' calculations.
} 
roles played by cultural links and language have received growing attention from economists seeking to explain trade and other types of international economic transactions in recent years, see in particular Mélitz (2002) and Guiso et al. (2005). However, FDI has been rarely studied in this context, despite the well-known similarities between trade and FDI and their common analytical framework. The role played by cultural differences in influencing the choice and mode of international economic transactions is, however, better known in business literature. For instance, Kobut and Singh (1988) find that national cultural differences have a significant effect in the choice of entry mode (i.e. either greenfield or joint venture) of foreign investors in the US. Similarly, Makino and Neupert (2000) show that the propensity to choose between a joint venture and full foreign ownership varies between Japanese and the U.S. firms depending on the direction of FDI flow. Cultural differences may play a role not only through the decision to invest in a foreign market or the mode of investment but also in the duration and potential success of foreign operations if, in particular, the well-being of expatriates is directly affected by cultural proximity between the home and host countries of foreign multinationals, see Jun et al. (2001). Furthermore Manev and Stevenson (2001) show that managers working for multinationals tend to build up strong ties with their peers depending on the cultural distance between them. Cultural proximity and common language arguably stand as the natural explanation for these findings. In the academic as well as in the managerial arena, there is strong consensus that, as a consequence of the historical ties between Spain and Latin America, many Spanish multinationals decide to invest in this area in order to search for new business opotunity, see Guillén (2004 and 2005). Likewise, the evidence presented here suggests that cultural proximity (including language) provides a significant incentive for Spanish multinationals to invest in countries with which Spain has strong cultural ties. These ties in turn may be seen as comparative intangible assets which allow these firms to compete successfully with multinationals from other countries. However, the strength provided by these intangible assets is not a sufficient condition to explain why Spanish multinationals have become 
so prominent in some areas of the world, particularly in Latin America. The preceding modernisation and development of the Spanish economy and, in particular, the role played by inward foreign direct investment in this process, represent an important condition in this regard (see in particular Barrios and Strobl (2002) and Barrios et al. (2004)). For these purposes, as it is also remarked in Galen et al. (2007), the Spanish case can be considered as a salient illustration of Dunning's OLI paradigm and, in particular, of the role played by economic development processes in explaining the net-FDI position of a given country. ${ }^{2}$ Our analysis shows in particular that the OLI paradigm is also influenced by countryspecific attributes such as cultural and language characteristics, which may explain why firms from a given country (who all share these culture-specific attributes) can benefit from them and become particularly successful in competing with companies from other countries (who do not share these country-specific attributes) in investing in a given region The evidence presented here suggests furthermore that these country-specific intangible assets are made effective only after a given countrydevelopment threshold has been reached and major FDI inflows have taken place, so the Spanish case can also be considered as a good illustration of the $J$-curve of net outward direct investment (NOI) derived from Dunning's theory, see in particular Dunning and Narula (1996). In this context, NOI is assumed first to increase as a given country develops and attracts FDI inflows but then to decrease once a given threshold of economic development is reached as that country's external competitiveness increases. The NOI position of a country can thus be seen as a by-product of its development process. .Galan et al. (2007) set out that when managers of Spanish multinationals choose countries of Latin America when deciding to locate their investment, social and cultural factors play an important rule. The difference with respect to our analysis is that in Galan et al. (2007) companies were not asked about specific cultural or social factor; rather they were asked about the relevance of these factors for their overall FDI strategies, whereas in our work specific factors are taking account to determine the

\footnotetext{
${ }^{2}$ In OLI, "O" stands for Ownership, "L", for location and "I" for internalisation.
} 
role of cultural link in the location decisions of Spanish multinationals. Our paper provides supporting evidence for these views by considering the role played by between-country cultural difference in influencing the location choices of multinational companies. Our approach entails two steps. We first examine how language affects the location decisions of Spanish multinationals around the world. Our results show that two areas have most benefited from Spanish FDI: the EU and (neighbouring Portugal and, to some extent, France in particular) and Latin America. In the second step we further investigate the role played by culture-related variables in determining the location of Spanish multinationals in South American countries. We seek to unravel the influence of cultural proximity by studying the separate impact of a number of variables which are likely to characterise cultural proximity, such as whether the official language is Spanish, the number of years for which a particular country was a Spanish colony, the percentage of the population who are of European origin and the percentage of the population who are Roman Catholics (the dominant faith in Spain and most Latin American countries). We also build up a cultural link indicator using principal component analysis based on the variables just mentioned. Overall we find strong evidence for these variables. Our analysis based on the marginal effects of the different explanatory variables used reveals also that the cultural link is more important than any other factor in explaining the geographical distribution of Spanish multinationals around the world: on average the probability of investing in a Spanish-speaking country is found to be higher by around $38 \%$ than the probability of investing in a non-Spanish speaking country. Furthermore, even when considering Latin American countries alone, cultural ties (as measured by a composite indicator including language among other factors) considered as whole are found to increase the probability of Spanish firms investing in a given country by $44 \%$, suggesting that both language and cultural links as a whole have indeed played a key role in promoting Spanish direct investment abroad. 
The rest of the paper is organised as follows. Section 2 describes the empirical model used. Section 3 gives the data and provides some descriptive evidence. Econometric analysis is presented in Section 4, and Section 5 concludes.

\section{The Spanish FDI experience: from inward to outward FDI}

Foreign Direct Investment has played a crucial role in the modernisation and catching-up of the Spanish economy. Until recently, FDI in Spain was essentially dominated by substantial inward rather than outward flows of direct investment. Indeed, a large proportion of multinationals currently active in Spain established affiliates during the years following the country's accession to the European Community, see Barrios and Strobl (2005). Until the mid-1980s Spain was still a relatively protected, highly regulated economy with significant barriers to trade and FDI and also low levels of foreign direct investment inflows, despite the fact that FDI was made easier during the late 1950s-early 1960s, when FDI was first liberalized in order to promote economic development, see, in particular, De la Dehesa et al. (1991). Table 1 provides an overview of the trends in FDI inflows and outflows in Spain as percentages of GDP between 1980 and 2005. Since the mid-1980s, FDI inflows have increased substantially, reaching 2.5\% of Spanish GDP between 1987 and 1993. The same applies to FDI outflows, although to a lower extent as they represented on average only $0.6 \%$ of Spain's GDP up to the early 1990s. Outward FDI has substantially increased since then, and surpassed FDI inflows for the first time in the mid-1990s, reaching 3.7\% of Spain's GDP between the mid-1990s and early 2000s. This increase has been further strengthened in recent years, which FDI outflows from Spain have represented as much as $4.5 \%$ of Spanish GDP. The emergence of Spain as major investor abroad is therefore a rather recent phenomenon that started in the mid-1990s and has progressively caught up with FDI inflows. As a consequence, during the latter period, the stocks of outward and inward FDI have been comparable, representing roughly a third of Spain's GDP. 
Interestingly, the long-run trend in Spain's relative position in terms of inward and outward FDI stock can be related to the fast catching-up process experienced by the Spanish economy. Following the eclectic theory of FDI put forward by Dunning $(1977,1998)$, the relative position of a given country in terms of its net outward FDI stock position is directly influenced by its level of economic development which, in turn, is directly linked to the competitiveness of its business sector. This is what Dunning (1997) calls the "ownership" advantage of multinationals, which corresponds to the idea that firms invest abroad in order to internalise that advantage, compared to alternative strategies of exporting or licensing. An illustration of the trend can be provided in the ownership advantage of Spanish companies assuming that this advantage is directly correlated with the level of per capita GDP as per Dunning's argument. Figure 1 provides such an illustration by plotting the trend in the net inward stock of FDI (i.e. inward stock - outward stock divided by GDP) for Spain and comparing it to a number of European countries such as the United Kingdom, Germany, Portugal, and France. The plot for Spain shows a non-monotonous trend in its FDI position against its level of per capita GDP expressed in purchasing power parity in line with the arguments previously set out. Spain has therefore shifted from a net inward FDI position to a net outward FDI position as its economy developed, providing evidence for the so-called J-curve of net outward investment, see in particular Dunning and Narula (1996). It must, however, be noted that for high levels of GDP per capita, which correspond also to the end of the period considered here, Spain has also experienced a significant increase in FDI. Other EU countries considered here such as Germany, the UK and France have had a negative net inward FDI position, which means that they have been essentially outward investors rather than inward recipients of direct investments. By contrast, Portugal has had an experience similar to that of Spain, albeit more erratic, as its level of GDP per capita caught up to the EU average. Overall, however, Portugal has had a positive net FDI position over the period in question, which also corresponds to its lower per capita GDP level. 
Coming back to the Spanish experience, Spanish companies are now investing abroad in many sectors of activity in which they hold competitive advantages, primarily banking and finance and energy but also manufacturing industries, see Camino Blasco and Pradas Poveda (2001). We focus on the manufacturing industry for which we consider data on the location pattern of new establishments abroad as well as the acquisition of existing plants abroad. The data are taken from the Spanish Ministry of Economy (Dirección General de Economía Internacional y Transacciones Exteriores) and concern public authorization of direct investment which, for the time considered here, was compulsory for all direct investment, both inward and outward. Here we concentrate on Spanish outward FDI. Besides the sector of activity (following the European NACE nomenclature at the three-digit level) and size of investment (in current Euros), this database indicates the country of destination and the nature of each operation, i.e. whether each FDI corresponds to a greenfield investment, the acquisition of an existing company or a foreign loan taken on by an existing company. Here we focus on greenfield operations so as to consider the location of new businesses. The period covered by the database is 1988-1997.

Table 2 reports the geographical and industrial breakdown of Spanish FDI during the period 1988-1997. The first two columns indicate the share of each industry (in percentage terms) in the total FDI for the manufacturing industry. Two industries between them account for more than half of Spain's FDI, namely Food, Beverages and Tobacco and Energy and Metallic Minerals. However, in terms of number of operations, the sectoral distribution of FDI is much less skewed and the top sector is Metal Products and Electrical Machinery, which represented nearly a third of all the operations undertaken during the period. In terms of geographical breakdown, Europe appears to be the leading destination, with Portugal and France ranked first in most cases. Latin American countries appear to be the second major destination for FDI, with Mexico, Argentina and Brazil being the preferred destinations of Spanish investors in this region of the world. 


\section{Where do Spanish firm invest? Considering the influence of the cultural link in a model-based location decision approach}

In this Section we provide an econometric analysis of the determinants of Spanish investment abroad by considering the special case of the manufacturing industry. The econometric modeling approach puts special emphasis on market access, which is particularly relevant for the manufacturing industry. Market access is essentially a measure of market potential, measuring the export demand faced by each country given its geographical position and that of its trading partners. The idea that access to markets is important for factor incomes dates back at least to Harris (1954), who argued that the potential demand for goods and services produced in any one location depends on the distanceweighted GDP of all locations. We assume that each location decision is thus treated as a discrete choice made from among several alternatives. Each alternative (or region) is characterized by an expected profit level linked to the region's specific characteristics such as its market access and all factors potentially affecting the production costs in that particular location including wages, workforce qualification levels and so on. The location decisions of multinationals can be thought of as the result of profit maximization behavior. Head and Mayer (2004) provide a simple model-based approach in order to study the determinants of the location of multinational companies by considering the influence of distance, market access and competition. More details on the underlying theoretical model are provided in the Annex. This model can be used to estimate the revealed profitability of each location using discrete choice estimation techniques. Let $\mathrm{P}_{\mathrm{r}}$ be the probability of choosing region $\mathrm{r}$ as a location:

$$
\left.P_{r} \equiv \operatorname{prob}\left(\pi_{r}\right\rangle \pi_{k}\right)=\operatorname{prob}\left(\varepsilon_{k}\left\langle\varepsilon_{r}+b\left(X_{r}-X_{k}\right)\right), \quad \forall r \neq k\right.
$$

where the $X$ are the location-specific attributes for two alternative locations in countries $r$ and $k$ and the $\varepsilon$ are iii error terms according to a type I extreme-value distribution, the probability of choosing location $r$ becomes 


$$
P_{r}=\frac{e^{b X_{r}}}{\sum_{k=1}^{n} e^{b X_{k}}}
$$

The profit function of each firm $k$ locating in a particular region $j$ of a given country can be written as follows:

$$
\Pi_{k j t}=\beta_{1} X_{j t}+E_{k j t}
$$

where $X$ is the same set of covariates characterizing each region as in (1) and $E$ is the error term. This profit maximisation problem is a variant of the random utility maximisation model of McFadden (1974), as shown by Carlton (1983). Assuming that the $E$ components are independently distributed across $k$ and $j$ and that they follow a Weibull distribution, the model can thus be estimated as in McFadden (1974) using the conditional logit approach. The coefficients of (3) can be estimated by maximum likelihood procedures under the independence of irrelevant alternatives (iia) assumption. The iia assumption stipulates that the probability of choosing a region $r$ over an alternative $j$, given by $P_{r} / P_{j}$, depends only on the characteristics of these two regions and not on any other third choice. This implies that all alternatives should be comparable in terms of substitution patterns. If the latter does not hold, an alternative model is the nested logit model, where location choices are made as a sequence of choices and where subsets of regions meet the iia hypothesis, see McFadden (1978).

The size of the local market and access to other markets are likely to exert a strong influence on business location determinants. In particular, market access can magnify the influence of local demand on production structure and business location in presence of increasing returns to scale in production. In the context of FDI, market access can thus be thought of as exerting a strong attraction for foreign firms producing on a large scale and seeking to export their products to other regions and/or countries. Here we consider the influence of market access by means of the level of GDP of each country which is considered as a potential foreign location by Spanish multinational. Each alternative location is thus 
given a weighted GDP sum in which the weights are inversely proportional to the bilateral geographical distance. ${ }^{3}$

Despite the acceleration of the globalisation process, international markets are still highly fragmented. This is due in part to intangible barriers to trade such as cultural and language barriers. In considering the influence of the cultural link on FDI we include further control variables such as language and other cultural proxies and see how these variables influence the location choice of Spanish multinationals. We consider these variables together with the market access variable and other determinants of FDI such as corporate taxation, macroeconomic stability and governance, labour costs and skills and the cultural link. A number of variables are considered in order to capture this cultural link so as to match Spain's main cultural features with respect to language and religion. The data are taken from the CIA World Factbook database. ${ }^{4}$ First we consider the location of Spanish multinationals across the world and only use a dummy variable, which takes a value of one if the official language of a country is Spanish. Second we consider the location of Spanish multinationals in Latin America alone, in order to study more closely the influence of the cultural link and its various components. We consider four variables as being related to the cultural link. The first is the language variable mentioned above. The second is the percentage of population that is of Roman Catholic religion, which is deemed to be an important part of the cultural link given the predominance of Roman Catholicism in Spain. The expected sign for this variable is therefore positive. The third variable is the percentage of population that is of European origin assuming that the higher this proportion is the closer these strands of population are likely to be in cultural terms. The fourth variable is the number of years for which the Latin American countries considered were Spanish colonies, assuming that longer colonial links would also mean closer cultural and economic ties with Spain.

\footnotetext{
${ }^{3}$ The geographical distances between the capitals of the various countries are considered here, taken from Jon Haveman's website: http://www.haveman.org//
} 
Besides these cultural link variables we also consider a number of other variables usually considered in the context of business location choices across countries. The first is the level of corporate taxation. This variable is expected to display a negative sign as high corporate taxation is likely to deter multinationals from locating as it would reduce the after-tax rate of return of investments in a particular location, see de Mooij and Ederveen (2003). At the same time, regions and/or countries may use public subsidies and grants to attract firms of certain types, especially multinationals working in high value-added types of activity. In doing this they would expect the cost of attracting those firms to be more than offset by the rewards of attracting firms with potentially large spillovers for local industry and generating highly qualified employment. Most evidence on this issue concerns the US, and suggests that taxes and other public incentives play a significant role in the location choices of multinationals. The economic significance of such incentives is generally considered to be small, however, and usually outstripped by other factors such as the existence of backward/forward suppliers, good transport infrastructures and public services and skilled labour forces. Evidence concerning the EU is relatively scant. Devereux and Griffith (1998) examine the choice of location for US firms locating in the European market and find that the tax rate plays a significant role in the choice between alternative locations in Europe. The data used here is taken from the Heritage Foundation. ${ }^{5}$ Furthermore, since we consider the location of Spanish companies throughout the world, substantial differences in the degrees of foreign capital restriction are likely to exist and must be taken into consideration. The index used is taken (as for the corporate rate taxation) from the Heritage Foundation and ranks countries such that the more restrictions a country puts on foreign investment the higher the score is, so a negative relationship is expected between this variable and FDI.

\footnotetext{
${ }^{4}$ This database is available at https://www.cia.gov/cia/publications/factbook/index.html.

${ }^{5}$ The data is taken from http://www.heritage.org/index/.
} 
The last variable is the inflation rate $^{6}$, which is expected to display a negative sign. Inflation and the risk of inflation encourage certain types of spending and investment decisions. The costs of high, unstable inflation can be severe. It undermines the economy's ability to generate long-lasting growth and create jobs, it creates uncertainty for consumers and investors and it can lead to painful cycles of economic "boom and bust" that cause hardship for many economic agents. Likewise, high inflation erodes the value of incomes and savings.

\section{Econometric Results}

As indicated earlier, we first provide econometric results concerning the determinants of the location of Spanish multinationals, considering every country in the world as a potential location choice. Secondly, we analyse more specifically the location of such companies in Latin American countries in order to consider the role played by the cultural link in their choices. Table 3 provides the results of estimating equation (3) considering all the variables described in Section 3. The first column provides the base-specification where all sectors of activity are considered together. The variables generally display the expected signs for the coefficients estimated. The local market access variable is positive and significant at the $1 \%$ level, while the foreign capital restriction and corporate taxation variables are negative and significant as expected. The inflation variable is also negative as expected but its coefficient is insignificant. Column (2) shows the high-tech sectors only, applying the widely used OECD sectoral distinction between high and low-tech sectors in order to check the robustness of our results. The results for the low-tech sectors are displayed in Column (3). Overall the results are very similar regardless of which sectors are considered. Column (4) presents a dummy variable with a

\footnotetext{
${ }^{6}$ The data used here is taken from the "International Monetary Fund. International financial statistics" database. The inflation rate is expressed as a percentage increase in average prices over a year. The measure of inflation used in the IMF's database is based on the consumer price index for each country, representing changes in the price of a representative basket of goods and services sold in each country. The data is taken from http://www.imfstatistics.org/imf/.
} 
value of one when a Spanish multinational locates in one of the EU15 countries. ${ }^{7}$ The results show that this variable is positive and highly significant. As suggested earlier, membership of the EU largely favoured inward FDI to Spain. Our results show that it also favoured outward FDI given that access to the markets of EU member states favoured Spanish direct investment there as well. The coefficients estimated in Table 3 can be used to calculate the marginal effect of a given country-attribute for the location probability of a given multinational. Using in particular the results from Column (5) on the Spanish dummy variable and the usual transformation in conditional logit analysis the probability of a country being chosen as a location site by a typical Spanish firm is shown to increase by $38 \%$ (standard error $0.3 \%$ ) if the official language in the country is Spanish. Overall, therefore, Spanish FDI abroad has been strongly influenced by language proximity. It must be noted, however, that other variables have also played similarly important roles. For instance, the marginal effect calculated on the local market access variable is found be $260 \%$ (standard error $0.33 \%$ ), suggesting that market access and the influence of geographical proximity have played the most important role, while the marginal effect for the European Community dummy variable is $20 \%$ (standard error $0.02 \%$ ).

In order to consider the determinant of Spanish direct investments into Latin American countries we use the same empirical model as before with one distinct feature regarding the market access variable, in that we consider separately the role played by a given country's GDP and that of its neighbouring countries. We chose to do this because of the great disparity in the sizes of Latin American countries, with Mexico and Brazil being by far the largest of them. Furthermore, that disparity extends not only to the geographical size of these countries but also to the spatial concentration of their populations. The latter fact in particular means that when considering geographical distance between countries' capitals in building up our market access variable we are likely to miss the fact that in some countries, for instance Argentina and Uruguay, the main population

\footnotetext{
${ }^{7}$ The EU15 rather than the EU25 countries are considered because in the period considered the new
} 
concentrations are in fact located close to large population concentrations in other countries (Brazil in this case). In order to take into account these differences in the internal geographical distribution of populations we consider a population-weighted distance between the main cities in the Latin American countries considered here. Table 4 lists the major cities considered and their populations in 1995 for each Latin American country covered by the study.

Table 5 shows the results of the estimations. The first results show that, as before, market access plays a key role in determining the location of Spanish direct investment. The decomposition used here regarding local market access into its two components, i.e. the host country and its neighbours, shows that both variables display positive and significant coefficients. The influence of the taxation level and the degree of foreign capital restriction are no longer significant, suggesting that distinctive features are involved when Latin American countries are considered specifically. In what follows we consider proxies of the cultural link such as the percentage of Roman Catholics in the total population, the countries where the official language is Spanish (all those in the sample except Brazil), literacy rates, the total number of years for which a country was a Spanish colony, the percentage of European-origin population and a composite indicator that embeds all these variables into one. This last variable is obtained via principal component analysis and is used to capture the different features that may reflect the degree of cultural proximity. These different variables are not considered to determine directly the location decisions of Spanish businesses but rather to capture country-specific cultural characteristics that may condition the attractiveness of a Latin American country to Spanish investors. The first characteristic of the cultural link is, as before, represented by a dummy variable indicating whether a country has Spanish as its official language. Importantly, given that we now consider only the set of Latin American countries, in contrast to Table 3, this variable must be seen in fact as a variable indicating whether the country of location is Brazil, in which case its value would be zero. The

Eastern and Central European states had not yet joined the European Union. 
coefficient obtained for this variable is positive and significant, as shown in Column (2) of Table 5 suggesting that Brazil was not the preferred location choice of Spanish multinationals despite its size, the size of its economy and the role played by local market access for the location decisions of multinationals. The second characteristic of the cultural link that we consider here is the percentage of population who are Roman Catholics, because Catholicism is also the main religion in Spain. The results that include this variable are displayed in column (3). They show that this feature has indeed played a positive and significant role in attracting Spanish FDI. We also estimated our equation with a variable representing the total number of years for which a country was a Spanish colony. The results are shown in Column (4) of Table 5, and reveal that this variable is also positive and significant, although less significant than the other two cultural link variables considered earlier. Column (5) shows the percentage of population of European origin as an explanatory variable which is also deemed to capture part of the cultural link effect. This variable appears to be insignificant, however. Part of this result could come from co-linearity between the cultural link and location characteristics such as market access. Indeed, as explained above, we chose to break down the market access variable into two components: the size of the host economy, represented by the level of GDP, and the size of the neighbouring economies, using weighted distances between major Latin American cities, where the urban population is used as the weighting factor. When this is done, foreign market access may indeed capture the geographical proximity between major Brazilian, Uruguayan and Argentinean cities. Although we have no data available concerning the exact cities of location of Spanish multinationals, it can reasonably be assumed that Spanish investment in this area may also seek to access the markets of the whole area market and not only that of the host country. For instance, one can reasonably assume that Uruguayan or Argentinean cities such as Montevideo, Buenos Aires or La Plata located relatively close to Brazil may potentially be chosen for Spanish investment in order to access the Brazilian market while benefiting from host country attributes, in particular closer cultural ties. If this is true then 
a positive correlation may be expected between our foreign market access variable and some cultural link variables. In order to investigate this we re-run our equation dropping the foreign market access variable. Results concerning the share of population of European origin are displayed in Column (6). The results show that, this time, the aforementioned variable displays a positive and significant coefficient, suggesting that location-specific attributes such as foreign market access do indeed interact with cultural-link variables. In Columns (7) and (8) respectively we therefore re-estimate our equation including our composite cultural link variable by respectively including and excluding the foreign market access variable. The results show that the composite cultural link variable displays a positive and significant coefficient in both cases although the significance is higher when the foreign market access variable is excluded. Using the coefficients from Column (8), the probability of a country being chosen as a location site is found to increase by approximately $44 \%$ (standard error $0.6 \%$ ) if it has relatively major cultural links with Spain.

\section{Summary and conclusion}

This paper analyses the role played by the cultural link with a view to establishing the determinants of Spanish direct investment abroad. To that end we use an econometric model of the location choices of firms using conditional logit techniques applied to a set of Spanish manufacturing firms over the period 1988-1997. Our work tests whether culture and language proximity may have acted as country-specific assets for Spanish firms and whether those assets have had a significant influence on the location decisions of Spanish firms abroad. We consider language and cultural proximity within the framework of the OLI paradigm to explain both direct investment decisions and location choices. Our results show that the cultural link played an important role in the location choices of Spanish multinational companies abroad in the period considered. While the cultural link may not be the most important factor explaining the surge in Spanish investment since the beginning of the 1990s, it has certainly played a decisive role in the geographical location of that investment, explaining in turn 
the leading position attained by Spanish firms in Latin America. More generally, these results show that the cultural dimension (including language) is an important one in understanding outward investment dynamics and the relative strength of the "O" and "L" dimensions of the OLI paradigm. 


\section{Tables and Graphs}

Table 1: Foreign Direct Investment flows and stocks in the Spanish economy as a $\%$ of GDP, 1980-2005

\begin{tabular}{lllll}
\hline & $\mathbf{1 9 8 0 - 1 9 8 6}$ & $\mathbf{1 9 8 7 - 1 9 9 3}$ & $\mathbf{1 9 9 4 - 2 0 0 0}$ & $\mathbf{2 0 0 1 - 2 0 0 5}$ \\
\hline (1) FDI Outward flow & 0.24 & 0.59 & 3.69 & 4.50 \\
(2) FDI Inward flow & 1.34 & 2.55 & 2.66 & 3.53 \\
(3) FDI Outward stock & 2.39 & 4.39 & 12.68 & 33.55 \\
$\begin{array}{l}\text { (4) FDI Inward stock } \\
\text { (5) FDI net flows: (2) }\end{array}-$ & 15.64 & & 20.44 & 35.04 \\
(1) & 1.10 & 1.96 & -1.04 & -0.97 \\
(6) FDI net stock: $(4)-$ & & & \\
(3) & 2.25 & 11.37 & 7.76 & 1.48 \\
\hline
\end{tabular}

Sources: UNCTAD, European Commission and authors' computations

Table 2: Distribution of Spanish FDI by manufacturing sector, continent and country *

\begin{tabular}{|c|c|c|c|c|}
\hline Sectors of activity & $\begin{array}{l}\text { \% value } \\
\text { total FDI }\end{array}$ & $\begin{array}{l}\% \text { \# of } \\
\text { operations }\end{array}$ & $\begin{array}{l}\text { Major recipient } \\
\text { continents } \\
\text { (\# of operations) }\end{array}$ & $\begin{array}{l}\text { Major recipient countries } \\
\text { (\# of operations) }\end{array}$ \\
\hline Food, beverages \& Tobacco & 0.21 & 0.15 & $\begin{array}{l}\text { Europe (125), North America (36), } \\
\text { South America (30) }\end{array}$ & $\begin{array}{l}\text { Portugal (54), France (46), US (23), } \\
\text { Argentina (12), Mexico (12) }\end{array}$ \\
\hline Transport & 0.02 & 0.06 & $\begin{array}{l}\text { Europe (54), North Africa (18), } \\
\text { North America (11) }\end{array}$ & $\begin{array}{l}\text { Portugal (12), France (10), Argentina } \\
\text { (7), Mexico (5), Canada (2) }\end{array}$ \\
\hline Non-metallic minerals & 0.11 & 0.07 & $\begin{array}{l}\text { Europe (57), South America (19), } \\
\text { North America (11) }\end{array}$ & $\begin{array}{l}\text { Morocco (18), Portugal (15), France } \\
\text { (12), Italy (10), UK (10) }\end{array}$ \\
\hline Paper \& Printing & 0.06 & 0.07 & $\begin{array}{l}\text { Europe (62), South America (29), } \\
\text { North America (12) }\end{array}$ & $\begin{array}{l}\text { Portugal (48), Morocco (9), France (7), } \\
\text { Argentina (6), Brazil (5) }\end{array}$ \\
\hline $\begin{array}{l}\text { Metal products } \\
\text { and electric machinery }\end{array}$ & 0.14 & 0.28 & $\begin{array}{l}\text { Europe (217), South America (78), } \\
\text { North America (52) }\end{array}$ & $\begin{array}{l}\text { Portugal (30), France (13), Italy (10), } \\
\text { Mexico (8), Argentina (6) }\end{array}$ \\
\hline Energy and metallic minerals & 0.37 & 0.06 & $\begin{array}{l}\text { Europe (43), South America (19), } \\
\text { North America (12) } \\
\text { Europe (124), South America (36) }\end{array}$ & $\begin{array}{l}\text { Portugal (96), France (47), Italy (28), } \\
\text { Mexico (27), Venezuela (26) } \\
\text { Portugal (27), US (10), Argentina (9) }\end{array}$ \\
\hline Chemical products & 0.04 & 0.16 & $\begin{array}{l}\text { North America (32) } \\
\text { Europe (66), North Africa (38), }\end{array}$ & $\begin{array}{l}\text { UK (5), France (4) } \\
\text { Portugal (65), France (23), Mexico (23), }\end{array}$ \\
\hline Textiles and leather & 0.03 & 0.09 & North America (10) & Morocco (15), Italy (12) \\
\hline Other industries & 0.01 & 0.04 & $\begin{array}{l}\text { Europe (28), South America (11), } \\
\text { North America (9) }\end{array}$ & $\begin{array}{l}\text { Morocco (35), Portugal (25), France } \\
\text { (17), Italy (12), Mexico (5) }\end{array}$ \\
\hline $\begin{array}{l}\text { Total } \\
\text { (value in current Bio Euros) }\end{array}$ & $1.00(3.43)$ & $1.00(3.43)$ & $1456(3.43)$ & $1.00(3.43)$ \\
\hline
\end{tabular}

\footnotetext{
* Concerns Greenfield investments only
} 
Table 3: Determinants of Spanish direct investment abroad: results for all countries Results from conditional logit estimation. (+) positive sign expected (-) negative sign expected

\begin{tabular}{llllll}
\hline & $(1)$ & $(2)$ & $(3)$ & $(4)$ & $(5)$ \\
\hline Local market access (+) & 0.114 & 0.133 & 0.092 & 0.047 & 0.151 \\
& $(0.019)^{* *}$ & $(0.025)^{* *}$ & $(0.028)^{* *}$ & $(0.022)^{*}$ & $(0.023)^{* *}$ \\
Distance (-) & -0.340 & -0.329 & -0.351 & -0.258 & -0.403 \\
& $(0.014)^{* *}$ & $(0.020)^{* *}$ & $(0.021)^{* *}$ & $(0.016)^{* *}$ & $(0.021)^{* *}$ \\
Corporate taxation (-) & -0.365 & -0.341 & -0.389 & -0.583 & -0.500 \\
& $(0.051)^{* *}$ & $(0.071)^{* *}$ & $(0.074)^{* *}$ & $(0.053)^{* *}$ & $(0.054)^{* *}$ \\
Foreign capital restrictions (-) & -0.032 & -0.030 & -0.035 & -0.034 & -0.031 \\
& $(0.001)^{* *}$ & $(0.002)^{* *}$ & $(0.002)^{* *}$ & $(0.002)^{* *}$ & $(0.002)^{* *}$ \\
Inflation (-) & -0.137 & -0.270 & -0.057 & -0.087 & 0.117 \\
& $(0.106)$ & $(0.199)$ & $(0.125)$ & $(0.106)$ & $(0.105)$ \\
EU (+) & & & & 1.404 & 1.192 \\
& & & & $(0.077)^{* *}$ & $(0.080)^{* *}$ \\
Spanish (+) & & & & 1.756 \\
& & & & \\
Observations & 85560 & 43680 & 41880 & 85560 & 85560 \\
Pseudo R-squared & 0.14 & 0.13 & 0.14 & 0.17 & 0.19 \\
Standard errors in parentheses, * significant at 5\%; ** significant at $1 \%$ & & \\
\hline
\end{tabular}


Table 4: Population data for Latin American countries and largest cities

(figures in ' 000 people)

\begin{tabular}{|c|c|c|c|c|}
\hline Country & City & population in 1995 & population of country & $\begin{array}{l}\text { proportion of population of the } \\
\text { country }\end{array}$ \\
\hline Argentina & Buenos Aires & 11,620 & 34,768 & 0.33 \\
\hline Argentina & Córdoba & 1,278 & 34,768 & 0.04 \\
\hline Argentina & Rosario & 1,189 & 34,768 & 0.03 \\
\hline Bolivia & $\mathrm{La} \mathrm{Paz}$ & 1,267 & 7,414 & 0.17 \\
\hline Brazil & Belém & 1,465 & 159,346 & 0.01 \\
\hline Brazil & Belo Horizonte & 3,755 & 159,346 & 0.02 \\
\hline Brazil & Brasília & 1,768 & 159,346 & 0.01 \\
\hline Brazil & Campinas & 1,595 & 159,346 & 0.01 \\
\hline Brazil & Curitiba & 2,226 & 159,346 & 0.01 \\
\hline Brazil & Fortaleza & 2,608 & 159,346 & 0.02 \\
\hline Brazil & Goiânia & 1,001 & 159,346 & 0.01 \\
\hline Brazil & Manaus & 1,188 & 159,346 & 0.01 \\
\hline Brazil & Porto Alegre & 3,328 & 159,346 & 0.02 \\
\hline Brazil & Recife & 3,068 & 159,346 & 0.02 \\
\hline Brazil & Rio de Janeiro & 10,159 & 159,346 & 0.06 \\
\hline Brazil & Salvador & 2,793 & 159,346 & 0.02 \\
\hline Brazil & Santos & 1,169 & 159,346 & 0.01 \\
\hline Brazil & São Paulo & 16,469 & 159,346 & 0.10 \\
\hline Chile & Santiago & 5,029 & 14,210 & 0.35 \\
\hline Colombia & Barranquilla & 1,396 & 38,542 & 0.04 \\
\hline Colombia & Bogotá & 5,716 & 38,542 & 0.15 \\
\hline Colombia & Cali & 1,819 & 38,542 & 0.05 \\
\hline Colombia & Medellín & 2,403 & 38,542 & 0.06 \\
\hline Ecuador & Guayaquil & 1,843 & 11,460 & 0.16 \\
\hline Ecuador & Quito & 1,376 & 11,460 & 0.12 \\
\hline El Salvador & San Salvador & 1,140 & 5,669 & 0.20 \\
\hline Guatemala & Guatemala City & 2,577 & 9,976 & 0.26 \\
\hline Mexico & Guadalajara & 3,431 & 91,145 & 0.04 \\
\hline Mexico & León & 1,127 & 91,145 & 0.01 \\
\hline Mexico & Mexico City & 16,791 & 91,145 & 0.18 \\
\hline Mexico & Monterrey & 2,961 & 91,145 & 0.03 \\
\hline Mexico & Puebla & 1,932 & 91,145 & 0.02 \\
\hline Mexico & Tijuana & 1,017 & 91,145 & 0.01 \\
\hline Puerto Rico & San Juan & 1,305 & 3,696 & 0.35 \\
\hline Uruguay & Montevideo & 1,299 & 3,218 & 0.40 \\
\hline Venezuela & Barquisimeto & 828 & 21,844 & 0.04 \\
\hline Venezuela & Caracas & 3,007 & 21,844 & 0.14 \\
\hline Venezuela & Ciudad Guayana & 628 & 21,844 & 0.03 \\
\hline Venezuela & Maracaibo & 1603 & 21,844 & 0.07 \\
\hline Venezuela & Valencia & 1462 & 21,844 & 0.07 \\
\hline Costa Rica & San José & 858 & 3,374 & 0.25 \\
\hline Honduras & Tegucigalpa & 814 & 5,654 & 0.14 \\
\hline Panama & Panama City & 998 & 2,631 & 0.38 \\
\hline Peru & Lima & 6,667 & 23,532 & 0.28 \\
\hline Nicaragua & Managua & 870 & 4,426 & 0.20 \\
\hline Paraguay & Asunción & 1,081 & 4,828 & 0.22 \\
\hline
\end{tabular}

Source: United Nations, Statistics Division and authors' calculations, cities with more than 750.000 people. 
Table 5: Determinants of Spanish direct investment abroad: results for Latin America

Results from conditional logit estimation. (+) positive sign expected (-) negative sign expected

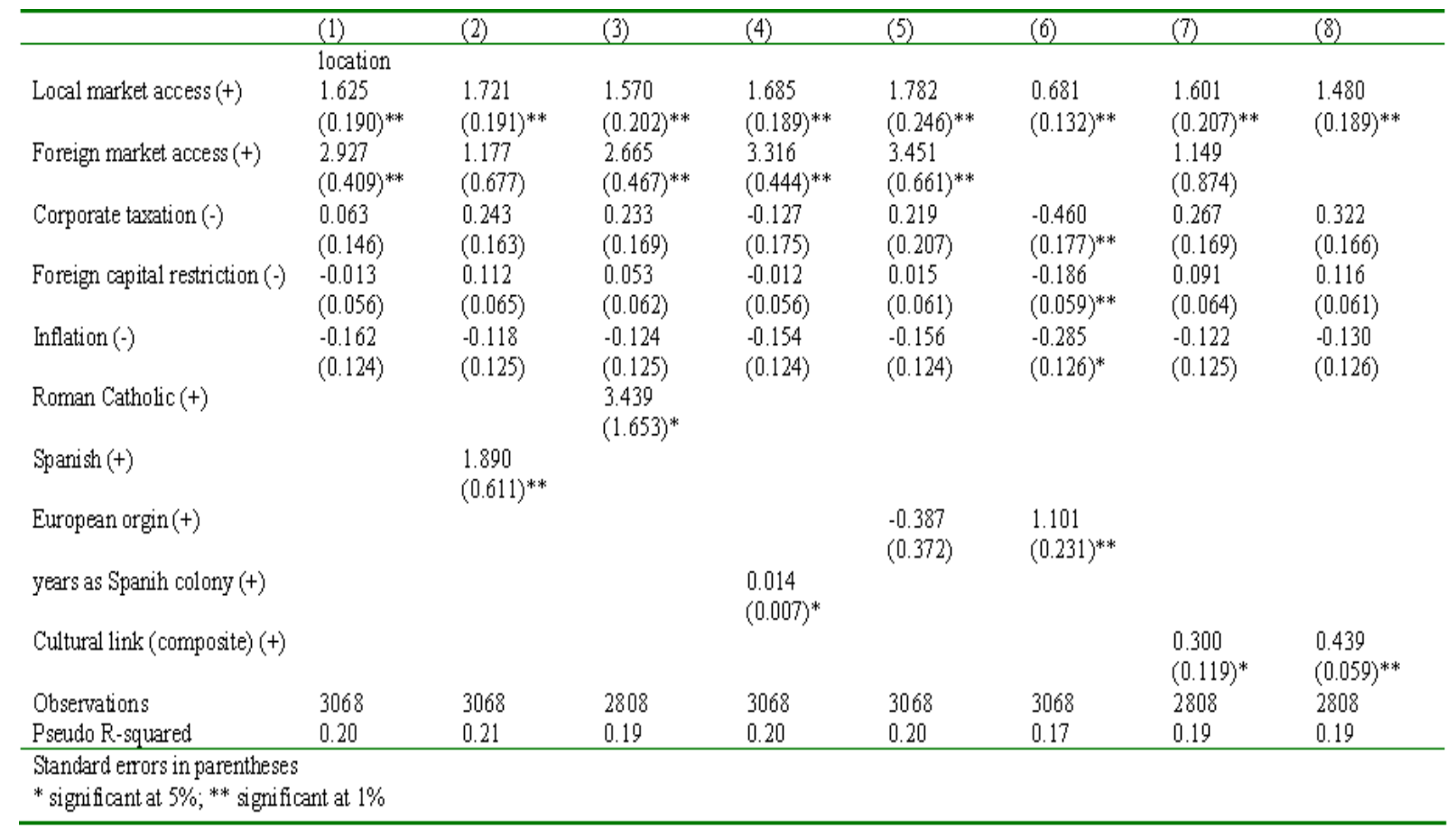


Figure 1: Net foreign direct investment stock (in \% of GDP) vs. GDP per capita level (in constant dollars) in Spain, the UK, Germany, Portugal and France (1980-2001).

Sources: UNCTAD, European Commission and authors' calculations.

Spain

\section{$F D I / G D P$}

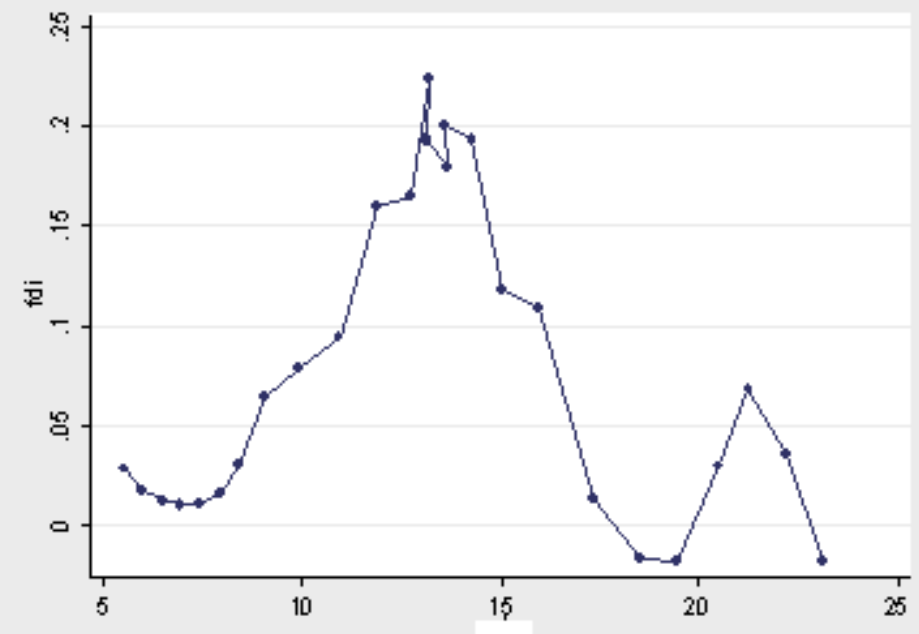

GDP per capita

\section{United Kingdom}

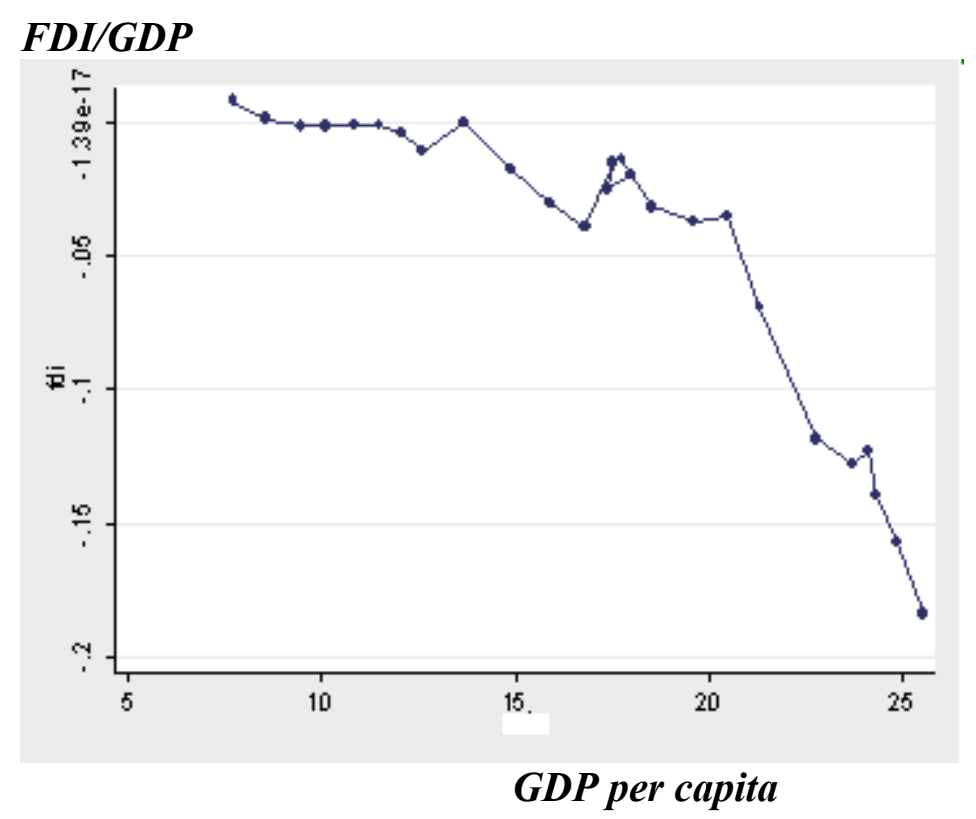




\section{Germany}

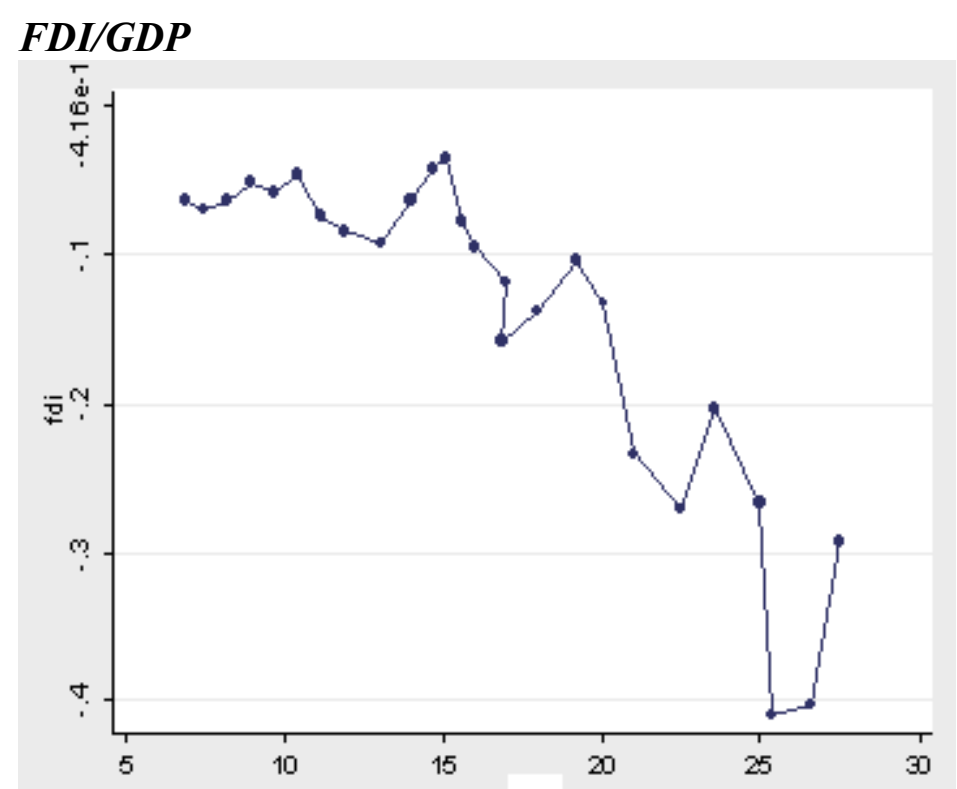

\section{GDP per capita}

\section{Portugal}

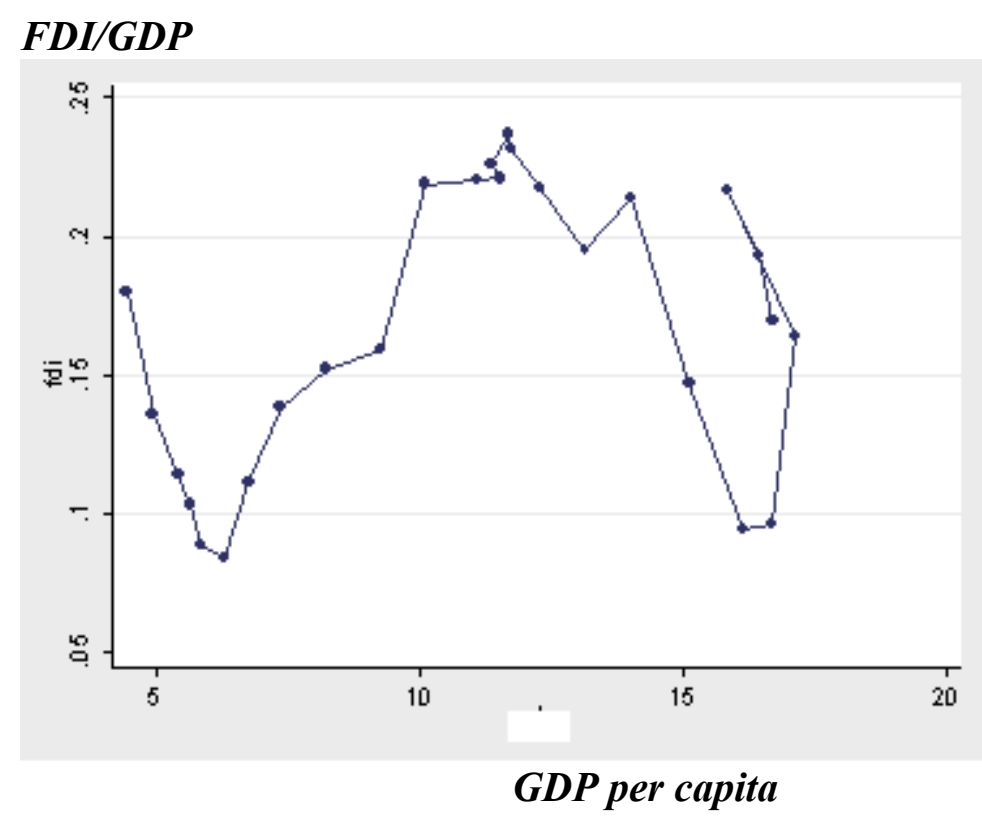




\section{France}

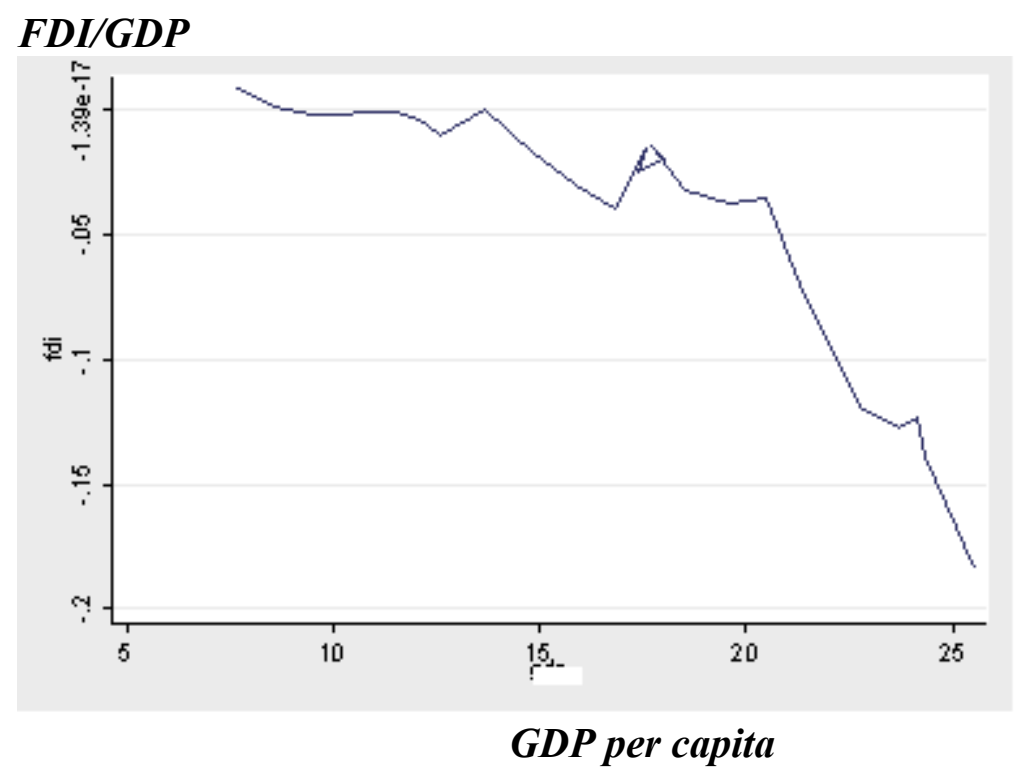




\section{Annex: the Head-Mayer (2004) location model for multinationals}

As mentioned in Section 3, the location decisions of multinationals can be thought of as the result of profit maximization behaviour. Following Dixit and Stiglitz (1977), Head and Mayer (2004) provide a simple model approach for studying the determinants of the location of multinational companies by considering the influence of distance, market access and competition. Let $E_{r}$ be the expenditure on a variety of a good produced by a given industry. Consumers have constant elasticity of substitution $(\sigma)$ between varieties such that demand for each industry can be derived from a sub-utility function on the good produced by that industry only. The demand for each product variety can be written as:

$$
q_{i j}=\frac{p_{i j}^{-\sigma}}{\sum_{r=1}^{R} n_{r} p_{r j}^{1-\sigma}} E_{j}
$$

where $p_{i j}=p_{j} \tau_{i j}, p_{j}$ is the mill price, $n_{r}$ is the number of varieties in region $r$ and $\tau_{i j}$ is the trade costs between two regions $i$ and $j$. In such a model, competition is monopolistic such that each firm treats the elasticity of substitution between product varieties as if it was the price elasticity of demand. The mill prices $p_{j}$ are thus simply markups over marginal costs $\left(c_{j}\right)$ that we assume to be region-specific, such that:

$$
p_{j}=c_{j}\left(\frac{\sigma}{\sigma-1}\right)
$$

Using (1) and (2) the quantity sold in each region $j$ by a firm producing in a region $i$ can be derived as follows:

$$
q_{i j}=\frac{\sigma-1}{\sigma} \frac{\left(c_{i} \tau_{i j}\right)^{\sigma}}{G_{j}} E_{j}
$$

where $G_{j} \equiv \sum_{r} n_{r}\left(c_{r} \tau_{i j}\right)^{-\sigma}$

The profit earned in each region $r$ is thus: 


$$
\pi_{r}=\frac{c_{r}^{1-\sigma}}{\sigma} M_{r}-F_{r}
$$

where $M_{r} \equiv \sum_{j} \frac{\tau_{i j}^{1-\sigma} E_{j}}{G_{j}}$ is the so-called Market Access term. The first term of on the right of equation (4) is the gross profit of each market, and we are interested in the total profit earned for a multinational located in a given region $r$. For this reason, we add $F_{r}$ which denotes the fixed $\operatorname{cost}^{8}$ to the profits earned in each market, in order to obtain the net profit earned in location $r$. Equation (4) therefore suggests that the location choice of firms is mainly determined by region-specific production costs and market access.

\footnotetext{
${ }^{8}$ We assume a very simple cost structure: all firms have a fixed cost in each region $F_{r}$, and a marginal cost in each region referred to as $c_{r}$.
} 


\section{References}

Barrios, S., S. Dimelis, H. Louri and E. Strobl, (2004), "Efficiency spillovers from foreign direct investment in the EU periphery: a comparative study of Greece, Ireland and Spain", Review of World Economics 140 (4): 688-705, 2004.

Barrios, S. and E. Strobl, (2002), Foreign Direct Investment and Productivity Spillovers: Evidence from the Spanish Experience. Review of World Economics 138(3): 459-481.

Camino Blasco, D. and J.I. Pradas Poveda, (2001), Los procesos de integración economica regional y la política de promoción de inversión extranjera directa. Un aproximación al caso español, Información Comercial Española n $^{\circ} 794$, Ministerio de Economía y de Hacienda, Spain.

Devereux, M.P. and R. Griffith, (1998), Taxes and the Location of production: evidence from a panel of US multinationals, Journal of Public Economics 68: 335-367.

De la Dehesa, G., J.J. Ruiz and A. Torres, (1991), Liberalizing Foreign Trade: Spain. IN: Papageorgiou, M. Mihcaely, and. Armeane (eds), Liberalizing Forign Trade. The Experience of New Zealand, Spain and Turkey. Cambridge, Mass., Blackwell.

Disdier A-C., and T. Mayer (2004). "How Different is Eastern Europe? Structure and determinants of location choices by French firms in Eastern and Western Europe", Journal of Comparative Economics $32,280-296$.

Dixit, A. and J. Stiglitz, (1977), "Monopolistic Competition and Optimun Product Diversity", American Economic Review 67(3), 297-308.

Dunning, J.H., (1977), "Trade, Location of Economic Activity and the Multinational Enterprise: a search for an Eclectic Approach", In: B. G. Ohlin, P.O. Hesselborn and P.M. Wijkman (eds.), The International allocation of Economic Activity, Holmes \& Meier Publishers, London.

Dunning, J.H., (1998), "Location and the Multinational Enterprise: A Neglected Factor?", Journal of International Business Studies 29: 45-66.

Dunning, J.H. and R. Narula (1996), Foreign Direct Investment and Governments. Catalysts for economic restructuring. Routledge Studies in International Business and the World Economy, London.

Galan, J.I., J. González-Benito and J.A. Zuñiga-Vincente, (2007), "Factors determining the location decisions of Spanish MNEs: an analysis based on the investment development path", Journal of International Business Studies 38: 975-997.

Guillén, M.F., (2004), "La internacionalización de las empresas españolas", Información Comercial Española, 812: 211-224.

Guillén, M.F., (2005), The Rise of Spanish Multinationals: European Business in the Global Economy, Cambridg University Press: Cambridge. 
Guiso, L., P. Sapienza and L. Zingales, (2005), Cultural biases in economic exchange, CEPR discussion paper $\mathrm{n}^{\circ} 4837$.

Guimarães, P., Figueiredo, P. and D. Woodward, (2000), "Agglomeration and the location of foreign direct investment in Portugal", Journal of Urban Economics 47(1), 115-135.

Harris, C., (1954), "The market as a factor in the localization of industry in the United States". Annals of the Association of American Geographers 64, 315-348.

Head, K., Ries, J.C., and Swenson, D.L., (1995), Agglomeration benefits and location choice: Evidence from Japanese manufacturing investments in the United State, Journal of International Economics 38, 223-247.

Head, K. and T. Mayer, (2004), "Market potential and the location of Japanese investment in the European Union", Review of Economics and Statistics 86(4):959-972.

Jun, S., J.W.Gentry and Y. J. Hyun, (2001) "Cultural Adaptation of Business Expatriates in the Host Marketplace", Journal of International Business Studies 32: 369-377

Kogut, B. and H. Singh (1988), "The Effect of National Culture on the Choice of Entry Mode", Journal of International Business Studies 19, 411-432.

Makino, S. and K. E. Neupert (2000), "National Culture, Transaction Costs, and the Choice Between Joint Venture and Wholly Owned Subsidiary" Journal of International Business Studies 31: 705-713.

Manev, I.M. and W.B. Stevenson (2001), " Nationality, Cultural Distance, and Expatriate Status: Effects on the Managerial Network in a Multinational Enterprise, Journal of International Business Studies, Vol. 32 (2): 285-303.

Mélitz, J. (2002), Language and Foreign Trade, CEPR discussion paper n³590.

Mooij, R.A. de, and S. Ederveen, (2003). Taxation and Foreign Direct Investment: a Synthesis of Empirical Research, International Tax and Public Finance 10, 673-693.

Toral Cuetos, P. (2004), Las Ventajas de las compañías españolas en América Latina, 1990-2000, Información Comercial Española, 812, Ministerio de Economía y de Hacienda, Spain. 